\title{
Carbon supported PdM (M = Fe, Co) electrocatalysts for formic acid oxidation. Influence of the $\mathrm{Fe}$ and Co precursors
}

L. Juárez-Marmolejo ${ }^{a}$, S. Pérez-Rodríguez ${ }^{b}, M$. G. Montes de Oca-Yemha ${ }^{*}$, M. Palomar-Pardavéa, M. Romero-Romo ${ }^{a}$, A. Ezeta-Mejía ${ }^{c}$, P. Morales-Gild M. V. Martínez-Huertae ${ }^{e}$ M. J. Lázaro-Elorrib ${ }^{*}$

a Universidad Autónoma Metropolitana-Azcapotzalco, Departamento de Materiales, C.P.02200, CDMX, México.

b Instituto de Carboquímica, CSIC, Miguel Luesma Castán 4, 50018 Zaragoza, España.

c Instituto Politécnico Nacional, ESIQIE. Departamento de Ingeniería Metalúrgica, UPALM Ed. 7, C.P. 07738, CDMX, México.

d Instituto Mexicano del Petróleo, Laboratorio de Caracterización de Materiales Sintéticos y Naturales, Eje Central Lázaro Cárdenas 152, CDMX, CP 07730, México. e Instituto de Catálisis y Petroleoquímica, CSIC, C/Marie Curie 2, 28049 Madrid, España.

* Corresponding authors emails:

mgmy@correo.azc.uam.mx (MGMY) and mlazaro@icb.csic.es (MJLE)

\begin{abstract}
$\mathrm{Pd}$ and $\mathrm{PdM}(\mathrm{M}=\mathrm{Fe}$ and $\mathrm{Co})$ nanostructured electrocatalysts were synthesized by the impregnation method and supported on carbon black Vulcan XC-72R for the formic acid oxidation reaction, FAOR, in acid medium. Nitrates or chlorides were used as Fe and Co precursors to study the counter ion role on the physicochemical features and electrochemical performance of the electrocatalysts. TEM analysis showed that PdM was deposited on the carbon material with a particle size around 2-3 nm. From XRD, peaks associated with the fcc palladium planes were observed along with evidence of PdM alloy formation, particularly when the nitrate salts were used as metal precursors. Furthermore, XPS analyses indicated that nitrates promote the metal oxide formation to a greater extent than chlorides, mainly for $\mathrm{Pd}$. PdCo electrocatalyst obtained from nitrates exhibited the highest performance for FAOR with a steady state current density of 451 and $313 \mu \mathrm{A} \mathrm{cm} \mathrm{cm}^{-2}$ at 200 and 400 $\mathrm{mV}$ respectively, which is in both cases, 3 times larger than that developed for a commercial $\mathrm{Pd} / \mathrm{C}$ catalyst.
\end{abstract}


Key words: Palladium; palladium-iron; palladium-cobalt; formic acid oxidation; $\mathrm{CO}$ oxidation

\section{Introduction}

Direct formic acid fuel cells (DFAFCs) have attracted considerable interest as a promising alternative for clean energy generation due to their overall efficiency and low pollutant emissions [1] The use of formic acid as fuel presents potential advantages such as its non-toxicity, stability at ambient temperature and low permeation through the Nafion ${ }^{\circledR}$ membrane (crossover effect) [2-5]. In addition, formic acid can be used in high concentrations, up to $20 \mathrm{M}$ as compared with methanol $[4,6,7]$.

Further, it has been stated that the formic acid oxidation reaction (FAOR) mechanism possibly evolves through either a direct or an indirect route. The former involves its direct oxidation into carbon dioxide, whereas dehydration of formic acid to adsorbed carbon monoxide and its subsequent oxidation into carbon dioxide constitutes the latter [8-11].

The rate of FAOR can increase when using an electrocatalyst that usually consists of metal nanoparticles dispersed on convenient carbon materials with different structures, morphologies and sizes [12]. These carbonaceous supports increase the active surface area and hence, enhance the electrochemical activity. In addition, carbon supported materials display adequate physicochemical and chemical properties, such a large specific surface area, high conductivity and stability, which play a fundamental role on the overall electrocatalysts efficiency [13].

Electrocatalysts based on Pt and its alloys have been widely studied for FAOR. Although generally speaking Pt-based electrodes exhibit a good performance toward FAOR, different disadvantages must be addressed, such as its high cost and the surface poisoning arising from significant $\mathrm{CO}$ adsorption as reaction intermediary, which blocks the direct formic acid oxidation [14]. In order to improve the FAOR efficiency, notable efforts have been made into designing more active electrocatalysts. Pd has attracted special attention due to its higher activity for FAOR 
as compared with pure Pt [14-18]. It is well known that Pd-based catalysts favor oxidation reactions of various organic molecules such as: methanol, ethanol and formic acid. This is because the use of Pd-based as a catalyst has some advantages as tolerance to $\mathrm{CO}$ as well as, good catalytic activity $[19,20]$.

However, the stability of monometallic Pd is not satisfactory and its performance needs to be improved in terms of $\mathrm{CO}$ tolerance. In order to address these issues, the use of bimetallic nanocatalytic systems adding a second transition metal, such as $\mathrm{Fe}, \mathrm{Co}, \mathrm{Ir}, \mathrm{Au}, \mathrm{Cu}, \mathrm{Sn}, \mathrm{Ni}, \mathrm{Ag}$ to the Pd structure have been proposed [21-33]. Several electrocatalysts synthesis methods have been reported in the literature, which usually involve the reduction of a metal salt with a chemical agent (e.g. $\mathrm{H}_{2}$, sodium borohydride, ethylene glycol, hydrazine) [34-36]. Different metal precursor salts have been used such as chlorides, nitrates and sulfates. However, up to now the role of the counter ion of the metal precursor salt on the catalytic performance has not been thoroughly studied. The use of different counter ions could result in electrocatalysts with different physicochemical properties and thus, the activity for FAOR could be modified.

This work deals with the effect of $\mathrm{Fe}$ and Co precursor $(\mathrm{P})$ salts namely: chlorides $(\mathrm{Cl})$ or nitrates $(\mathrm{N})$ on the electrochemical performance toward FAOR of PdM-P/C ( $\mathrm{M}=\mathrm{Fe}$ or $\mathrm{Co})$ electrocatalysts. Carbon-supported electrocatalysts were synthesized by the impregnation method using sodium borohydride as reducing agent. Iron/Cobalt chloride/nitrates were used as metal precursors. $\mathrm{Pd} / \mathrm{C}$ catalyst was also synthesized as comparison. The resulting catalysts were characterized by different analytical techniques such as $\mathrm{X}$-ray diffraction (XRD), transmission electron microscopy (TEM) and energy dispersive X-ray spectroscopy (EDX) analysis. The electrochemical performance was studied by cyclic voltammetry and chronoamperometry in $0.5 \mathrm{M} \mathrm{H}_{2} \mathrm{SO}_{4}$. Under laboratory temperature conditions, namely $25^{\circ} \mathrm{C}$.

\section{Experimental Setup}




\subsection{Electrocatalysts synthesis}

The carbon-supported Pd electrocatalyst was synthesized using sodium borohydride, $\mathrm{NaBH}_{4}$ (Sigma-Aldrich, 99.9\%) as reducing agent and the commercial carbon black Vulcan XC-72R (Cabot) as support. Briefly, the carbon Vulcan was dispersed in deionized water followed by ultrasonication for 1 hour. Subsequently, a $5 \mathrm{mM} \mathrm{Na}_{2} \mathrm{PdCl}_{4}$ (Sigma Aldrich, 98\%) solution was added to that containing the support and the $\mathrm{pH}$ was set to 5 with $0.5 \mathrm{M} \mathrm{NaOH}$ (Sigma-Aldrich, 99.99\%); then, a $26 \mathrm{mM} \mathrm{NaBH}_{4}$ solution was added slowly. The resulting electrocatalyst (named as $\mathrm{Pd} / \mathrm{C}$ ) was filtered followed by repeated washing and drying at $70^{\circ} \mathrm{C}$ overnight.

For PdFe and PdCo catalysts, the Pd precursor was $5 \mathrm{mM}$ of $\mathrm{H}_{2} \mathrm{PdCl}_{4}$ synthesized as follows: $\mathrm{PdCl}_{2}$ (Sigma-Aldrich, 99\%) was diluted and brought to boiling with hydrochloric acid, $0.25 \mathrm{M} \mathrm{HCl}$ (Sigma-Aldrich, 36.5\%) under reflux. Then $5 \mathrm{mM} \mathrm{Fe}$ or Co precursor chlorides or nitrates-base salts were dissolved in water. Nitrate $\left(\mathrm{Fe}\left(\mathrm{NO}_{3}\right)_{3} \cdot 9 \mathrm{H}_{2} \mathrm{O}\right.$, Sigma-Aldrich, $98 \%$; $\mathrm{Co}\left(\mathrm{NO}_{3}\right)_{2} \cdot 6 \mathrm{H}_{2} \mathrm{O}$, Sigma-Aldrich, $98 \%$ ) or chloride ( $\mathrm{FeCl}_{3}$, Sigma-Aldrich, $97 \%$; $\mathrm{CoCl}_{2} \cdot 6 \mathrm{H}_{2} \mathrm{O}$, Sigma-Aldrich, $98 \%$ ) salts were used as metal precursors to obtain the corresponding PdM-P/C ( $\mathrm{M}=\mathrm{Fe}$ or $\mathrm{Co}$ ) electrocatalysts. Finally, the mixture of both metallic precursors was added to the support dispersion following the same synthesis method used for the $\mathrm{Pd} / \mathrm{C}$ catalyst. Catalysts obtained from nitrates were denoted as PdM-N/C, while those obtained from chlorides were labeled as PdM-Cl/C. The metal molar ratio in the PdFe and PdCo electrocatalysts was 1:1. Appropriate amounts of metal precursors were used to obtain a theoretical metal loading of $20 \mathrm{wt} \%$ onto Vulcan XC-72R.

\subsection{Physicochemical characterization}

The Pd-based electrocatalysts were characterized by EDX, XRD, XPS and TEM to study the composition, structure and particle size of the resulting nanoparticles, as well as their dispersion onto the carbon support.

To establish the powder electrocatalyst composition a Hitachi S-3400N SEM equipment was used coupled with a Röntec XFlash $\mathrm{Si}(\mathrm{Li})$ detector for EDX analysis. 
XRD patterns were recorded using a Bruker AXS D8 Advance diffractometer with a $\theta-\theta$ configuration and $\mathrm{Cu} K \alpha$ radiation $(\lambda=0.15406 \mathrm{~nm})$. Scans were carried out at $1.0^{\circ} \mathrm{min}^{-1}$ for $2 \theta$ values from 10 to $80^{\circ}$.

TEM micrographs were obtained in a JEOL-2000 FXII microscope equipped with a LaB6 gun operated at $200 \mathrm{keV}$. The samples were dispersed in ethanol, and a drop of the resulting dispersion was carefully deposited on a copper grid. Particle size distribution of the synthesized electrocatalysts was obtained using the Digital Micrograph software counting over 200 particles from different areas.

XPS measurements were performed in an Escalab 250 Thermo Scientific (base pressure $\sim 2 \times 10^{-9}$ mbar) equipment with an Al filament emitting $X$ rays at $1486.6 \mathrm{eV}$. The Avantage 5 software was used for fitting the XPS profiles with GaussianLorentzian (GL) line shape functions, calibrated by assigning a binding energy (BE) value of $285 \mathrm{eV}$ to the $\mathrm{C} 1 \mathrm{~s}$.

\subsection{Electrochemical characterization}

The electrochemical performance of the synthesized electrocatalysts was studied by means of cyclic voltammetry (CV) and chronoamperometry (CA) in a conventional three-electrode electrochemical cell coupled with a $\mu$-Autolab Metrohm type III series

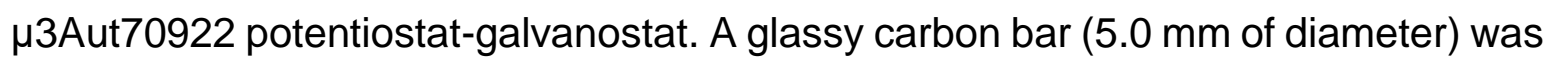
used as working electrode substrate, together with a graphite bar as counter electrode and a $\mathrm{Ag} / \mathrm{AgCl} / 3.0 \mathrm{M} \mathrm{KCl}$ inserted in a Luggin capillary as reference electrode, to which all potentials herein are referred to. The working electrodes were prepared as follows: first, the glassy carbon surface was polished with $0.3 \mu \mathrm{m}$ alumina slurry, followed by water washing and sonication. Then, a $20 \mu \mathrm{L}$ aliquot of each electrocatalyst ink was deposited over the glassy carbon electrode and subsequently dried under a $\mathrm{N}_{2}$ (INFRA air products, High purity) stream. Catalyst inks were prepared mixing $2 \mathrm{mg}$ of the corresponding electrocatalyst with $15 \mu \mathrm{L}$ of Nafion (5\% wt. \% alcohol base, Sigma-Aldrich) and $500 \mu \mathrm{L}$ of ultrapure water (Milli$\left.\mathrm{Q}^{\circledR} 18.2 \mathrm{M} \Omega \cdot \mathrm{cm}\right)$. The mixture was sonicated for 40 minutes to obtain a homogeneous suspension. 
Electrochemical experiments were carried out at room temperature and atmospheric pressure. The working electrode was immersed in the supporting electrolyte $0.5 \mathrm{M}$ $\mathrm{H}_{2} \mathrm{SO}_{4}$ (Sigma Aldrich, $99.999 \%$ ) deaerated with $\mathrm{N}_{2}$. The electrocatalysts were cycled from -200 to $1000 \mathrm{mV}$ at $500 \mathrm{mV} \mathrm{s}^{-1}$ for 20 complete cycles to clean the surface. Then, 3 cyclic voltammograms (CVs) were recorded at $20 \mathrm{mV} \mathrm{s}^{-1}$ in the same potential range to activate the surface. The last voltammogram was termed as blank.

CO-stripping voltammograms were monitored to study the performance of the catalysts toward CO electrooxidation. For such a purpose, CO (INFRA air products, High purity) was adsorbed on the electrocatalyst by bubbling it through the working electrolyte during $15 \mathrm{~min}$ at $-170 \mathrm{mV}$. Then, the solution was saturated with $\mathrm{N}_{2}$ for $20 \mathrm{~min}$ to remove the $\mathrm{CO}$ excess and a cyclic voltammetry was carried out from -200 to $1000 \mathrm{mV}$ at $20 \mathrm{mV} \mathrm{s}^{-1}$ for 3 cycles. Electrochemically active surface areas, EASA, were obtained by the ratio between the experimental charge (obtained by $\mathrm{CO}$ stripping peak integration) and the charge density corresponding to a $\mathrm{CO}$ adsorbed monolayer oxidation on $\mathrm{Pd}$ polycrystalline surface $\left(315 \mu \mathrm{C} \mathrm{cm}{ }^{-2}\right)$ [23]. The faradaic currents were normalized by the respective EASA to obtain the current densities ( $\mu \mathrm{A}$ $\mathrm{cm}^{-2}$ ) given in the text.

The FAOR voltammograms were assessed in $0.5 \mathrm{M} \mathrm{H}_{2} \mathrm{SO}_{4}+2.0 \mathrm{M} \mathrm{HCOOH}$ (Sigma Aldrich, $95 \%$ ) by cycling the potential between -200 and $1000 \mathrm{mV}$ at $20 \mathrm{mV} \mathrm{s}^{-1}$. Chronoamperometry evaluation of the current density response at steady state conditions (jss) was carried out stepping the potential to 200 and $400 \mathrm{mV}$, both for 900 seconds.

The electrochemical performance of the synthesized catalysts was compared with that obtained using a commercial Pd/C catalyst (Sigma-Aldrich, 30 wt. \%). This electrocatalyst has been labeled as $\mathrm{PdsA} / \mathrm{C}$ in the text.

\section{Results and discussion}

\subsection{Physicochemical characterization}


The metal content of the Pd-based catalysts was studied by EDX (Table 1). All the laboratory-made electrocatalysts presented a metal loading similar to the nominal value (20 wt.\%). Additionally, the EDX atomic ratio was around 50:50 for the bimetallic catalysts in agreement with the theoretical values.

Figure 1a shows the XRD patterns of $\mathrm{PdsA} / \mathrm{C}$ and synthesized electrocatalysts. $A$ characteristic peak at around $2 \theta=25^{\circ}$, associated with the graphite (002) diffraction plane of the support was shown by all synthetized electrocatalysts. Also, their diffraction patterns exhibit three characteristic peaks at around $2 \theta=40.09^{\circ}, 46.63^{\circ}$ and 68.08 ${ }^{\circ}$, which are assigned to (111), (200) and (220) planes of $\mathrm{Pd}$ fcc. Comparing the position of Pd-related peaks of the synthesized $\mathrm{Pd} / \mathrm{C}$ catalyst and bimetallic catalysts, a shift to higher $2 \theta$ values was observed for the bimetallic catalysts obtained from nitrate salts (see Table 1 and Figure 1b), which may be explained by the contraction of the $\mathrm{Pd}$ lattice structure by the introduction of the second metal Fe or Co. However, this shift is not as evident for catalysts obtained from chlorides due to a lower alloying degree. Other authors have obtained poor alloying after using synthesis methods of electrocatalysts involving low temperatures [20, 37-40]. Reduction treatments at higher temperatures or the control of other experimental conditions (such as $\mathrm{pH}$, concentration, reducing agent, stabilizing agent, synthesis method) resulted in nanoparticles with an improved alloying degree, as well as cluster-type and core-shell morphologies [18, 41-43]. Finally, monometallic $\mathrm{Pd}$ catalysts $(\mathrm{Pd} / \mathrm{C}$ and $\mathrm{PdsA} / \mathrm{C})$ showed a diffraction peak around $34^{\circ}$ associated to $\mathrm{PdO}$ formation. $\mathrm{PdM}-\mathrm{Cl}$ catalyst displays some relatively low intensity peaks on the $\mathrm{XRD}$ patterns at $2 \theta=35.76^{\circ}$ and $65.63^{\circ}$ that can be associated with $\mathrm{Fe}_{3} \mathrm{O}_{4}$ and $\mathrm{Co}_{3} \mathrm{O}_{4}$ respectively.

In order to further characterize the catalysts, the XPS technique was used. Figure 2 presents XPS spectra recorded from PdM catalysts synthesized in this work. From these images it is possible to note that regardless of the precursor salt, Co (see Figure 2a) and Fe (see Figure 2b) were fully oxidized at the surface. In the case of Co the main component was $\mathrm{Co}_{3} \mathrm{O}_{4}[44,45]$ while for $\mathrm{Fe}$ it was present as a mixture of $\mathrm{FeO}, \mathrm{Fe}(\mathrm{OH})_{2}(\mathrm{Fe}(\mathrm{II}))$ and $\mathrm{Fe}_{3} \mathrm{O}_{4}(\mathrm{Fe}(\mathrm{II})$ and $\mathrm{Fe}(\mathrm{III}))$ species [46]. As can be noted 
from Figures $2 \mathrm{c}$ (chloride precursor) and $2 \mathrm{~d}$ (nitrate precursor), $\mathrm{Pd}$ was formed by $\mathrm{Pd}(0), \mathrm{PdO}(\mathrm{Pd}(\mathrm{II}))$ and $\mathrm{PdO}_{2}(\mathrm{Pd}(\mathrm{IV}))$. However, the metal to oxide ratio was greater when the chloride precursor was used, this result was the same regardless of the second metal.

Figure 3 shows the TEM images and particle size distributions of the synthesized electrocatalysts. In general, a good dispersion of the metal nanoparticles on the carbon support was obtained for all the samples. In addition, narrow particle size distributions were obtained for all Pd-based electrocatalysts with a mean particle size ranging from 2 to $3 \mathrm{~nm}$. These results show that the chloride and nitrate salts did not have a significant effect on the sizes of the nanoparticles obtained. According to the bibliography nanoparticles with an average size around of 2.2 to $9.0 \mathrm{~nm}$ have a good electrocatalytic activity towards the FAOR [3, 27]. Thus, the synthesized electrocatalysts seem to be promising candidates for FAOR. Finally, the commercial catalyst presented larger average particle size $(7 \mathrm{~nm})$.

\subsection{Electrochemical characterization}

\subsubsection{Electrochemical features in the base electrolyte}

The electrochemical features of the $\mathrm{Pd}$-based synthesized catalysts was evaluated in $0.5 \mathrm{M} \mathrm{H}_{2} \mathrm{SO}_{4}$ by cyclic voltammetry, cycling the potential from -200 to $1000 \mathrm{~V}$ at $20 \mathrm{mV} \mathrm{s}^{-1}$ and starting from the open circuit potential (OCP) in the anodic direction. The blank voltammograms obtained for all synthesized catalysts are shown in Figure 4.

All the electrocatalysts evidenced the characteristic Pd features reported in the literature [27, 47]. The potential scan in the negative direction shows hydrogen adsorption/absorption, followed by the hydrogen evolution reaction at potentials below $-150 \mathrm{mV}$. During the anodic sweep, hydrogen desorption takes place and palladium oxide is formed at potentials greater than $600 \mathrm{mV}$, which are reduced in the negative scan at around $500 \mathrm{mV}$. In the potential interval from 100 to $200 \mathrm{mV}$ 
the current density remains constant and is associated to interfacial electrical control (double layer). Interestingly, the PdFe electrocatalyst synthesized using nitrates as a metal precursor (PdFe-N/C) presented another oxidation peak from 300 to $500 \mathrm{mV}$ which could be associated with the oxidation of exposed Fe. Han and $\mathrm{Xu}$ [48] synthesized PdFe alloy nanoparticles, where the voltammogram, see Figure $4 \mathrm{a}$ in 48, also showed an oxidation peak prior to that of $\mathrm{Pd}$ oxide formation, that corresponded to the electrochemical oxidation of exposed Fe atoms from the surface layer.

\subsubsection{CO stripping}

CO stripping voltammetry was used to obtain the electroactive surface area (EASA) of $\mathrm{Pd}$-based electrocatalysts and to evaluate the catalyst surface tolerance for $\mathrm{CO}$ poisoning. Figure 5 shows the results obtained for all the electrocatalysts.

During the anodic sweep of the first scan (solid curves) the hydrogen adsorption/ absorption/desorption region is totally blocked confirming that $\mathrm{CO}$ was adsorbed at the catalyst surfaces. Two peaks attributed to $\mathrm{CO}$ electrooxidation are discerned for all the electrocatalysts, with the exception of the commercial catalyst which presented a main peak at $723 \mathrm{mV}$. The location of the peaks depends on the electrocatalyst: the first contribution (peak I) is centered within the 558 to $673 \mathrm{mV}$, while the second one (peak II) occurs at potentials from 707 to $723 \mathrm{mV}$. Bimodal CO oxidation profiles have been already reported by other authors on Pd electrocatalysts supported on carbon materials [47, 49,50]. The maximum oxidation potentials of both peaks and the onset potential for the $\mathrm{CO}$ oxidation reaction are summarized in Table 2.

A different catalytic activity toward $\mathrm{CO}$ electrooxidation is evident, which is ascribed

to differences in the size and structure of metal nanoparticles [51]. In this context, the commercial catalyst requires a more positive potential to oxidize CO compared with the synthesized $\mathrm{Pd} / \mathrm{C}$. In fact, the main oxidation occurs at $716 \mathrm{mV}$ in the catalyst obtained by reduction with $\mathrm{NaBH}_{4}$, while $723 \mathrm{mV}$ are required in the commercial one. Further, the first oxidation contribution does not appear at $\mathrm{PdsA} / \mathrm{C}$ surface. These results clearly indicate that the synthesized catalyst with a particle 
size around 2 to $3 \mathrm{~nm}$ display an improved activity toward $\mathrm{CO}$ oxidation than the commercial catalyst with a larger particle size. Thus, larger particle sizes led to a less activity for $\mathrm{CO}$ removal.

The second metal addition (Fe or $\mathrm{Co}$ ), favored $\mathrm{CO}$ oxidation since the onset potential shifted to more negative potentials from $538 \mathrm{mV}$ at $\mathrm{Pd} / \mathrm{C}$ to $423-507 \mathrm{mV}$ for the bimetallic electrocatalysts. Thus, bimetallic surfaces seem to favor $\mathrm{CO}$ oxidation. In addition, an improved condition for $\mathrm{CO}$ removal was obtained on the bimetallic catalyst PdCo-N/C compared to PdCo-Cl/C. Similar particle sizes (2 to $3 \mathrm{~nm}$ ) were obtained for all the samples and hence, these differences are associated with the different composition/structure of the catalysts. Nitrate precursors resulted in a higher alloying degree (in agreement with the XRD results), which seems to favor the activity towards $\mathrm{CO}$ electrooxidation in the case of the PdCo catalyst. Interestingly, the PdCo-N/C catalyst exhibited the lowest potential for the main oxidation peak (peak II) with a current density $\left(85.25 \mu \mathrm{Acm}^{-2}\right)$ maximum at $707 \mathrm{mV}$. Peak I appeared also at low potentials $(620 \mathrm{mV})$.

Finally, it is important to note that after $\mathrm{CO}$ oxidation the electrochemical behavior is similar to the blanks reported before (compare red lines in Figure 5 with lines of Figure 4), which evidences that $\mathrm{CO}$ was removed completely from the base electrocatalyst.

\subsubsection{Formic acid oxidation reaction}

The performance of the electrocatalysts toward FAOR was studied in $0.5 \mathrm{M} \mathrm{H}_{2} \mathrm{SO}_{4}$ $+2.0 \mathrm{M} \mathrm{HCOOH}$ cycling the potential from -200 to $1000 \mathrm{mV}$ Figure 6 shows the results of all the catalysts.

All the Pd-based electrocatalysts display similar features: during the positive-going potential scan, a rise in the faradaic current density is evident, exhibiting an anodic peak with its maxima dependent on the catalyst (in the 270 to $638 \mathrm{mV}$ potential range). A close inspection of FAOR voltammograms evidences that bimetallic catalysts present the maxima at potentials around $200-300 \mathrm{mV}$ during the positivegoing potential scan, with the exception of $\mathrm{PdFe}-\mathrm{Cl} / \mathrm{C}$ with the main oxidation (488 $\mathrm{mV}$ ) at potentials similar to monometallic Pd catalysts (448 at $\mathrm{Pd} / \mathrm{C}$ and $638 \mathrm{mV}$ at 
the commercial electrode). In the cathodic sweep, once $\mathrm{Pd}$ oxide reduction takes place, formic acid is again re-oxidized displaying even higher current densities than those developed during the anodic excursion, which is explained by a high tolerance to catalyst poisoning $[50,52]$. Table 3 displays the main oxidation potential $\left(E_{p}\right)$ and the peak current density $\left(j_{p}\right)$ developed during the anodic excursion.

PdsA/C displayed the largest current density but the main peak for formic acid oxidation during the anodic excursion appeared at more positive potentials. Indeed, the anodic peak position developed during the forward scan of $\mathrm{Pd}$-based electrocatalysts follows this sequence: $\mathrm{PdsA} / \mathrm{C}(638 \mathrm{mV})>\mathrm{PdFe}-\mathrm{Cl} / \mathrm{C}(488 \mathrm{mV})>$ $\mathrm{Pd} / \mathrm{C}(448 \mathrm{mV})>\mathrm{PdCo}-\mathrm{Cl} / \mathrm{C}(287 \mathrm{mV})>\mathrm{PdFe}-\mathrm{N} / \mathrm{C}(273 \mathrm{mV})>\mathrm{PdCo}-\mathrm{N} / \mathrm{C}(270 \mathrm{mV})$. Thus, the second metal addition in general resulted in an improved condition toward FAOR for all the electrocatalysts, with the exception of $\mathrm{PdFe}-\mathrm{Cl} / \mathrm{C}$. This catalyst presented a behavior similar to the synthesized monometallic catalyst $(\mathrm{Pd} / \mathrm{C})$. In other words, bimetallic electrodes showed the highest current density toward FAOR in the potential range from 200 to $300 \mathrm{mV}$, while pure $\mathrm{Pd}$ catalysts and $\mathrm{PdFe}-\mathrm{Cl} / \mathrm{C}$ presented a higher efficiency at potentials around $400-600 \mathrm{mV}$.

As is well known, for the electrocatalytic oxidation of $\mathrm{HCOOH}$, there are usually involved the so-called dual pathways, which are dehydrogenation and dehydration, as represented by reactions (1) and (2), respectively [53, 54] :

$\mathrm{COOH} \rightarrow \mathrm{CO}_{2}+2 \mathrm{H}^{+}+2 \mathrm{e}^{-}$

$\mathrm{HCOOH} \rightarrow \mathrm{CO}_{\text {ads }}+\mathrm{H}_{2} \mathrm{O} \rightarrow \mathrm{CO}_{2}+2 \mathrm{H}^{+}+2 \mathrm{e}^{-}$

Although the dehydrogenation is the main pathway on $\mathrm{Pd}$ catalyst, recent studies reveal that $\mathrm{CO}_{\text {ads }}$ can still accumulate on the surface of $\mathrm{Pd}$, leading to the degradation of the catalytic performance over time under DFAFC conditions [55]. Therefore, according to the fact that $\mathrm{PdCo}-\mathrm{N} / \mathrm{C}$ catalyst showed high catalytic activity towards $\mathrm{CO}$ electrooxidation, it was expected good performance also during the formic acid electrooxidation.

The steady state anodic current density $\left(j_{s s}\right)$ was evaluated through chronoamperometry at 200 and $400 \mathrm{mV}$ during 900 seconds. The $j_{s s}-t$ plots for all the electrocatalysts are shown in Figure 7 , while Table 4 reports the current densities 
of the catalysts evaluated at 900 seconds at both potentials. The $j_{\mathrm{ss}}$ at $200 \mathrm{mV}$ followed this sequence: $\mathrm{PdCo}-\mathrm{N} / \mathrm{C}>\mathrm{PdFe}-\mathrm{N} / \mathrm{C}>\mathrm{PdsA} / \mathrm{C}>\mathrm{Pd} / \mathrm{C}>\mathrm{PdFe}-\mathrm{Cl} / \mathrm{C}>$ $\mathrm{PdCo}-\mathrm{Cl} / \mathrm{C}$, while the $j_{\mathrm{ss}}$ at $400 \mathrm{mV}$ followed this sequence: $\mathrm{PdCo}-\mathrm{N} / \mathrm{C}>\mathrm{PdFe}-\mathrm{N} / \mathrm{C}$ $>\mathrm{PdFe}-\mathrm{Cl} / \mathrm{C}>\mathrm{PdsA} / \mathrm{C}>\mathrm{Pd} / \mathrm{C}>\mathrm{PdCo}-\mathrm{Cl} / \mathrm{C}$.

Interestingly, the PdCo-N/C exhibited the largest current density at both potentials, with an anodic current density around two and three times larger than the monometallic catalysts $(\mathrm{Pd} / \mathrm{C}$ and $\mathrm{Pd} \mathrm{sA} / \mathrm{C})$.

Regarding the effect of the $\mathrm{Fe} / \mathrm{Co}$ metal precursor, the bimetallic catalysts obtained from nitrates (PdCo-N/C and PdFe-N/C) showed higher activity towards FAOR compared to their analogues $(\mathrm{PdCo}-\mathrm{Cl} / \mathrm{C}$ and $\mathrm{PdFe}-\mathrm{Cl} / \mathrm{C}$, respectively). Moreover, $\mathrm{PdCo}-\mathrm{N} / \mathrm{C}$ depicted better catalytic activity than $\mathrm{PdFe}-\mathrm{N} / \mathrm{C}$ probably due to a greater alloying degree between Pd and Co.

\section{Conclusions}

In this work, the effect of the $\mathrm{Fe} / \mathrm{Co}$ metal precursor salt (nitrates or chlorides) on the physicochemical properties and catalytic activity for $\mathrm{CO}$ oxidation and FAOR of $\mathrm{Pd}$ $\mathrm{M} / \mathrm{C}$ ( $\mathrm{M}=\mathrm{Fe}$ or $\mathrm{Co}$ ) electrocatalysts was studied. Catalysts were obtained by impregnation and reduction with sodium borohydride using iron/cobalt chloride/nitrates as metal precursors. Results were compared with a monometallic $\mathrm{Pd} / \mathrm{C}$ synthesized catalyst obtained by the same methodology.

XRD patterns evidenced that Pd was deposited on the carbon material with a fcc structure. In the case of bimetallic catalysts, the use of nitrates and chlorides allowed obtaining PdM alloys. However $\mathrm{Fe} / \mathrm{Co}$ precursors from nitrates showed higher alloying degree with $\mathrm{Pd}$, as compared with the $\mathrm{PdM}-\mathrm{Cl} / \mathrm{C}$ catalysts. XPS results demonstrated that nitrates favored the metal oxide formation. Furthermore, high dispersion of metal nanoparticles with an average size of 2-3 nm was observed by TEM for all the catalysts. 
CO-stripping voltammograms showed that the addition of the second metal (Fe or Co) resulted in an improved condition for $\mathrm{CO}$ removal.

Regarding the activity of catalysts toward FAOR, PdCo-N/C and PdFe-N/C exhibited the highest steady state anodic current densities.

\section{Acknowledgements}

LJM is grateful to CONACYT for the grant awarded for this research, as well as to the UAM-A and the ICB for the support provided. MGMY, MRR, MPP and AEM thank the SNI for the distinction of their membership and the stipend provided. MGMY is indebted to L'oreál-UNESCO-CONACYT-AMC for the grant Women in Science 2016. MJL and SPR gratefully acknowledge financial support given by Spanish MINECO (ENE2014-52158-C2-1-R).

\section{References}

[1] Rice C, Ha S, Masel R, Waszczuk P, Wieckowski A, Barnard T. Direct formic acid fuel cells. J Power Sources 2002;111:83-9.

[2] Yu X, Pickup PG. Recent advances in direct formic acid fuel cells (DFAFC). J Power Sources 2008;182:124-32.

[3] Zhu Y, Kang Y, Zou Z, Zhou Q, Zheng J, Xia B, et al. A facile preparation of carbon-supported $\mathrm{Pd}$ nanoparticles for electrocatalytic oxidation of formic acid. Electrochem Commun 2008;10:802-5.

[4] Aslam N, Masdar M, Kamarudin S, Daud W. Overview on direct formic acid fuel cells (DFAFCs) as an energy sources. APCBEE Procedia. 2012;3:33-9.

[5] Ong B, Kamarudin S, Basri S. Direct liquid fuel cells: A review. Int J Hydrogen Energy 2017;42:10142-57.

[6] Rice C, Ha S, Masel R, Wieckowski A. Catalysts for direct formic acid fuel cells. J Power Sources 2003;115:229-35.

[7] Rhee Y-W, Ha SY, Masel RI. Crossover of formic acid through Nafion® membranes. J Power Sources 2003;117:35-8. 
[8] Cuesta A, Cabello G, Osawa M, Gutiérrez C. Mechanism of the Electrocatalytic Oxidation of Formic Acid on Metals. ACS Catal 2012;2:728-38.

[9] Jiang K, Zhang H-X, Zou S, Cai W-B. Electrocatalysis of formic acid on palladium and platinum surfaces: from fundamental mechanisms to fuel cell applications. Phys Chem Chem Phys 2014;16:20360-76.

[10] Jeon H, Jeong B, Joo J, Lee J. Electrocatalytic oxidation of formic acid: closing the gap between fundamental study and technical applications. Electrocatalysis 2015;6:20-32.

[11] Cai W, Li J, Jiang Y, Liu C, Ma L, Xing W. Formic acid electro-catalytic oxidation at high temperature in supporting electrolyte free system: Mechanism study and catalyst stability. J Electroanal Chem 2016;761:68-73.

[12] Uhm S, Kwon Y, Chung ST, Lee J. Highly effective anode structure in a direct formic acid fuel cell. Electrochimica Acta 2008;53:5162-8.

[13] Carmo M, Paganin V, Rosolen J, Gonzalez E. Alternative supports for the preparation of catalysts for low-temperature fuel cells: the use of carbon nanotubes. J Power Sources 2005;142:169-76.

[14] Zhang X-G, Arikawa T, Murakami Y, Yahikozawa K, Takasu Y. Electrocatalytic oxidation of formic acid on ultrafine palladium particles supported on a glassy carbon. Electrochimica Acta 1995;40:1889-97.

[15] Zhou WP, Lewera A, Larsen R, Masel RI, Bagus PS, Wieckowski A. Size effects in electronic and catalytic properties of unsupported palladium nanoparticles in electrooxidation of formic acid. J Phys Chem B 2006;110:13393-8.

[16] Ge J, Xing W, Xue X, Liu C, Lu T, Liao J. Controllable synthesis of Pd nanocatalysts for direct formic acid fuel cell (DFAFC) application: from Pd hollow nanospheres to Pd nanoparticles. J Phys Chem C 2007;111:17305-10.

[17] Li H, Sun G, Jiang Q, Zhu M, Sun S, Xin Q. Synthesis of highly dispersed $P d / C$ electro-catalyst with high activity for formic acid oxidation. Electrochem Commun 2007;9:1410-5.

[18] Montes de Oca MaG, Plana D, Celorrio V, Lazaro MJ, Fermín DJ. Electrocatalytic properties of strained Pd nanoshells at Au nanostructures: $\mathrm{CO}$ and HCOOH oxidation. J Phys Chem C 2011;116:692-9. 
[19] Moraes L, Matos B, Radtke C, Santiago E, Fonseca F, Amico S, et al. Synthesis and performance of palladium-based electrocatalysts in alkaline direct ethanol fuel cell. Int J Hydrogen Energy 2016;41:6457-68.

[20] Rivera Gavidia LM, Sebastián D, Pastor E, Aricò AS, Baglio V. Carbonsupported $\mathrm{Pd}$ and $\mathrm{PdFe}$ alloy catalysts for direct methanol fuel cell cathodes. Materials 2017;10:580.

[21] Wang $\mathrm{X}$, Xia Y. Electrocatalytic performance of PdCo-C catalyst for formic acid oxidation. Electrochem Commun 2008;10:1644-6.

[22] Morales-Acosta D, Ledesma-Garcia J, Godinez LA, Rodríguez HG, ÁlvarezContreras L, Arriaga LG. Development of $\mathrm{Pd}$ and $\mathrm{Pd}-\mathrm{Co}$ catalysts supported on multi-walled carbon nanotubes for formic acid oxidation. J Power Sources 2010;195:461-5.

[23]Celorrio V, de Oca MM, Plana D, Moliner R, Fermin D, Lazaro M. Electrochemical performance of $\mathrm{Pd}$ and $\mathrm{Au}-\mathrm{Pd}$ core-shell nanoparticles on surface tailored carbon black as catalyst support. Int J Hydrogen Energy 2012;37:7152-60. [24] Celorrio V, Montes de Oca M, Plana D, Moliner R, Lázaro M, Fermín D. Effect of carbon supports on electrocatalytic reactivity of $\mathrm{Au}-\mathrm{Pd}$ core-shell nanoparticles. J Phys Chem C 2012;116:6275-82.

[25] Mazumder V, Chi M, Mankin MN, Liu Y, Metin Ö, Sun D, et al. A Facile Synthesis of $\mathrm{MPd}(\mathrm{M}=\mathrm{Co}, \mathrm{Cu})$ Nanoparticles and Their Catalysis for Formic Acid Oxidation. Nano Lett 2012;12:1102-6.

[26] Ji Y, Zhao R, Zhang G, Chen Y, Tang Y, Lu T. Room-temperature synthesis and electrocatalysis of carbon nanotubes supported palladium-iron alloy nanoparticles. Electrochimica Acta 2013;111:898-902.

[27] Liao M, Hu Q, Zheng J, Li Y, Zhou H, Zhong C-J, et al. Pd decorated Fe/C nanocatalyst for formic acid electrooxidation. Electrochimica Acta 2013;111:504-9. [28] Zhang L, Wan L, Ma Y, Chen Y, Zhou Y, Tang Y, et al. Crystalline palladiumcobalt alloy nanoassemblies with enhanced activity and stability for the formic acid oxidation reaction. App Catal B Environ 2013;138-139:229-35. 
[29] Al-Akraa I, M. Mohammad A, S. El-Deab M, El Anadouli B. Advances in Direct Formic Acid Fuel Cells: Fabrication of Efficient Ir/Pd Nanocatalysts for Formic Acid Electro-Oxidation Int J Electrochem Sci 2015;10:3282-90.

[30] Mao H, Huang T, Yu A. Electrochemical surface modification on CuPdAu/C with extraordinary behavior toward formic acid/formate oxidation Int $\mathrm{J}$ Hydrogen Energy 2016;41:13190-96.

[31] Vafaei M, Rezaei M, Tabaian SH, Mahboubi F, Haghshenas DF. Facile synthesis of a highly active $\mathrm{Pd} / \mathrm{Co}$ bimetallic nanocatalyst on carbon fiber cloth via a two-step electrodeposition for formic acid electrooxidation. J Solid State Electrochem 2015;19:289-98.

[32] Zhou Y, Du C, Han G, Gao Y, Yin G. Ultra-low Pt decorated PdFe alloy nanoparticles for formic acid electro-oxidation. Electrochimica Acta 2016;217:203-9. [33] Pires F, Villullas H. Pd-based catalysts: Influence of the second metal on their stability and oxygen reduction activity. Int J Hydrogen Energy 2012;37:17052-9.

[34] Aricò AS, Stassi A, D'Urso C, Sebastián D, Baglio V. Synthesis of Pd3Co1@ $\mathrm{Pt} / \mathrm{C}$ Core-Shell Catalysts for Methanol-Tolerant Cathodes of Direct Methanol Fuel Cells. Chem A Eur J 2014;20:10679-84.

[35] Matin MA, Jang J-H, Kwon Y-U. PdM nanoparticles ( $\mathrm{M}=\mathrm{Ni}$, Co, Fe, Mn) with high activity and stability in formic acid oxidation synthesized by sonochemical reactions. J Power Sources 2014;262:356-63.

[36] Ma Y, Li T, Chen H, Chen X, Deng S, Xu L, et al. A general strategy to the synthesis of carbon-supported $\mathrm{PdM}(\mathrm{M}=\mathrm{Co}, \mathrm{Fe}$ and $\mathrm{Ni}$ ) nanodendrites as highperformance electrocatalysts for formic acid oxidation. J Energy Chem 2017;26:1238-44.

[37] Calderón J, Nieto-Monge M, Pérez-Rodríguez S, Pardo J, Moliner R, Lázaro M. Palladium-nickel catalysts supported on different chemically-treated carbon blacks for methanol oxidation in alkaline media. Int J Hydrogen Energy 2016;41:19556-69. [38] Calderón J, Celorrio V, Nieto-Monge M, Fermín D, Pardo J, Moliner R, et al. Palladium-nickel materials as cathode electrocatalysts for alkaline fuel cells. Int $\mathrm{J}$ Hydrogen Energy 2016;41:22538-46. 
[39] Zhang Z, Xin L, Sun K, Li W. Pd-Ni electrocatalysts for efficient ethanol oxidation reaction in alkaline electrolyte. Int J Hydrogen Energy 2011;36:12686-97.

[40] Vecchio CL, Sebastián D, Alegre C, Aricò AS, Baglio V. Carbon-supported Pd and Pd-Co cathode catalysts for direct methanol fuel cells (DMFCs) operating with high methanol concentration. J Electroanal Chem 2018;808:464-73.

[41]Chen A, Ostrom C. Palladium-based nanomaterials: synthesis and electrochemical applications. Chem Rev 2015;115:11999-2044.

[42] Sun D, Si L, Fu G, Liu C, Sun D, Chen Y, et al. Nanobranched porous palladiumtin intermetallics: One-step synthesis and their superior electrocatalysis towards formic acid oxidation. J Power Sources 2015;280:141-6.

[43] Yan H, Bai Z, Chao S, Cui Q, Niu L, Yang L, et al. Effects of additives on palladium nanocrystals supported on multiwalled carbon nanotubes and their electrocatalytic properties toward formic acid oxidation. Ionics 2014;20:259-68.

[44] Petitto SC, Marsh EM, Carson GA, Langell MA. Cobalt oxide surface chemistry: The interaction of $\mathrm{CoO}\left(\begin{array}{lll}1 & 0 & 0\end{array}\right), \mathrm{Co} 3 \mathrm{O} 4\left(\begin{array}{lll}1 & 1 & 0\end{array}\right)$ and $\mathrm{Co} 3 \mathrm{O} 4\left(\begin{array}{lll}1 & 1 & 1\end{array}\right)$ with oxygen and water. J Mol Catal A-Chem 2008;281:49-58.

[45] Faisal F, Stumm C, Bertram M, Waidhas F, Lykhach Y, Cherevko S, et al. Electrifying model catalysts for understanding electrocatalytic reactions in liquid electrolytes. Nat Mater 2018:1.

[46] Gavidia LMR, García G, Anaya D, Querejeta A, Alcaide F, Pastor E. Carbonsupported Pt-free catalysts with high specificity and activity toward the oxygen reduction reaction in acidic medium. App Catal B Environ 2016;184:12-9.

[47] He N, Qin C, Wang R, Ma S, Wang Y, Qi T. Electro-catalysis of carbon black or titanium sub-oxide supported Pd-Gd towards formic acid electro-oxidation. RSC Adv 2016;6:68989-96.

[48] Han B, Xu C. Nanoporous PdFe alloy as highly active and durable electrocatalyst for oxygen reduction reaction. Int $\mathrm{J}$ Hydrogen Energy 2014;39:18247-55.

[49] Pérez-Rodríguez S, Rillo N, Lázaro M, Pastor E. Pd catalysts supported onto nanostructured carbon materials for $\mathrm{CO} 2$ valorization by electrochemical reduction. App Catal B Environ 2015;163:83-95. 
[50] Miyake H, Okada T, Samjeské G, Osawa M. Formic acid electrooxidation on Pd in acidic solutions studied by surface-enhanced infrared absorption spectroscopy. Phys Chem Chem Phys 2008;10:3662-9.

[51] Hoshi N, Kida K, Nakamura M, Nakada M, Osada K. Structural effects of electrochemical oxidation of formic acid on single crystal electrodes of palladium. $J$ Phys Chem B 2006;110:12480-4.

[52]Tang $\mathrm{Y}$, Edelmann RE, Zou S. Length tunable penta-twinned palladium nanorods: seedless synthesis and electrooxidation of formic acid. Nanoscale 2014;6:5630-3.

[53] Grozovski V, Climent V, Herrero E, Feliu JM. Intrinsic activity and poisoning rate for $\mathrm{HCOOH}$ oxidation on platinum stepped surfaces. Phys Chem Chem Phys 2010;12:8822-31.

[54] Zhang J, Chen M, Li H, Li Y, Ye J, Cao Z, et al. Stable palladium hydride as a superior anode electrocatalyst for direct formic acid fuel cells. Nano Energy 2018;44:127-34.

[55] Zhang LY, Zhao ZL, Li CM. Formic acid-reduced ultrasmall Pd nanocrystals on graphene to provide superior electocatalytic activity and stability toward formic acid oxidation. Nano Energy 2015;11:71-7. 
Table 1. Physical characteristics of the Pd-based electrocatalysts: total metal content and ratio obtained from EDX , $2 \Theta$ of $\mathrm{Pd}(111)$ from XRD and particle size from TEM of the electrocatalysts.

\begin{tabular}{|c|c|c|c|c|}
\hline \multirow{3}{*}{ Electrocatalyst } & \multirow{3}{*}{$\begin{array}{c}\text { XRD } \\
\text { Pd (111) } \\
\text { 2 Theta } \\
\text { / degree }\end{array}$} & \multirow{3}{*}{$\begin{array}{c}\text { TEM } \\
\text { Particle size } \\
\text { (nm) }\end{array}$} & \multirow{2}{*}{\multicolumn{2}{|c|}{$\begin{array}{c}\text { SEM-EDX } \\
\text { Elemental composition }\end{array}$}} \\
\hline & & & & \\
\hline & & & \begin{tabular}{|c|} 
Metal content \\
wt. $\%$
\end{tabular} & $\begin{array}{l}\text { Pd:M } \\
\text { at. \% }\end{array}$ \\
\hline $\mathrm{Pd} / \mathrm{C}$ & 40.10 & $2.98 \pm 0.69$ & 21.00 & 100 \\
\hline $\mathrm{PdsA} / \mathrm{C}$ & 40.09 & $7.00 \pm 1.19$ & 29.94 & 100 \\
\hline $\mathrm{PdFe}-\mathrm{Cl} / \mathrm{C}$ & 40.14 & $2.88 \pm 0.66$ & 18.94 & $45: 55$ \\
\hline $\mathrm{PdCo}-\mathrm{Cl} / \mathrm{C}$ & 40.12 & $2.89 \pm 0.65$ & 20.26 & $43: 57$ \\
\hline $\mathrm{PdFe}-\mathrm{N} / \mathrm{C}$ & 40.23 & $2.20 \pm 0.42$ & 17.91 & $45: 55$ \\
\hline $\mathrm{PdCo}-\mathrm{N} / \mathrm{C}$ & 40.33 & $2.60 \pm 0.47$ & 19.46 & $54: 46$ \\
\hline
\end{tabular}


Table 2. CO oxidation potentials from cyclic voltammograms shown in Fig. 5 and EASA from $\mathrm{CO}$ stripping for the different catalyst.

\begin{tabular}{|c|c|c|c|c|}
\hline Electrocatalyst & $\begin{array}{c}\text { CO } \\
\text { onset } \\
\text { potential } \\
(\mathbf{m V})\end{array}$ & $\begin{array}{c}\text { CO } \\
\text { oxidation } \\
\text { potential } \\
\text { peak - I } \\
(\mathbf{m V})\end{array}$ & $\begin{array}{c}\text { CO } \\
\text { oxidation } \\
\text { potential } \\
\text { peak - II } \\
(\mathbf{m V})\end{array}$ & $\begin{array}{c}\text { EASA } \\
\left(\mathbf{c m}^{2}\right)\end{array}$ \\
\hline $\mathbf{P d} / \mathbf{C}$ & 538 & 673 & 716 & 43.39 \\
\hline $\mathbf{P d s A / C}$ & 551 & -- & 723 & 13.16 \\
\hline $\mathbf{P d F e - C I / C}$ & 423 & 558 & 711 & 9.43 \\
\hline $\mathbf{P d C o - C l / C}$ & 507 & 664 & 717 & 17.06 \\
\hline $\mathbf{P d F e - N / C}$ & 437 & 610 & 722 & 9.94 \\
\hline $\mathbf{P d C o - N / C}$ & 488 & 620 & 707 & 18.41 \\
\hline
\end{tabular}


Table 3. Potential and current density of the voltammetric peaks of the CVs shown in Fig. 6.

\begin{tabular}{|c|c|c|}
\hline Electrocatalyst & $\begin{array}{c}\text { Ep } \\
(\mathbf{m V})\end{array}$ & $\begin{array}{c}\boldsymbol{j}_{\mathbf{p}} \\
\left(\mu \mathrm{A} \mathrm{\mathbf { } \mathrm { m } ^ { - 2 } )}\right.\end{array}$ \\
\hline $\mathrm{Pd} / \mathrm{C}$ & 448 & 819 \\
\hline $\mathbf{P d s A} / \mathbf{C}$ & 638 & 1573 \\
\hline $\mathbf{P d F e - C / C}$ & 488 & 550 \\
\hline PdCo-C/C & 287 & 915 \\
\hline PdFe-N/C & 273 & 738 \\
\hline PdCo-N/C & 270 & 908 \\
\hline
\end{tabular}


Table 4. Current density at steady state, at 200 and $400 \mathrm{mV}$ for $900 \mathrm{~s}$ in $2.0 \mathrm{M} \mathrm{HCOOH}+$ $0.5 \mathrm{M} \mathrm{H}_{2} \mathrm{SO}_{4}$.

\begin{tabular}{|c|c|c|}
\hline Electrocatalyst & $\begin{array}{c}j_{s s} \\
\text { at } 200 \mathrm{mV} \\
\left(\mu \mathrm{A} \mathrm{ccm^{-2 } )}\right.\end{array}$ & $\begin{array}{c}j_{s s} \\
\text { at } 400 \mathrm{mV} \\
\left(\mu \mathrm{A} \mathrm{cm}^{-2}\right)\end{array}$ \\
\hline $\mathrm{Pd} / \mathrm{C}$ & 157.3 & 96.9 \\
\hline Pdsa/C & 214.3 & 110.2 \\
\hline $\mathrm{PdFe}-\mathrm{Cl} / \mathrm{C}$ & 110.9 & 178.9 \\
\hline $\mathrm{PdCo}-\mathrm{Cl} / \mathrm{C}$ & 107.72 & 70.36 \\
\hline PdFe-N/C & 229.3 & 211.7 \\
\hline PdCo-N/C & 451.1 & 313.1 \\
\hline
\end{tabular}




\section{Figure Captions}

Figure 1. a) XRD patterns of the Pd-based electrocatalysts and b) Zoom around the 2 Theta $P d(111)$ region.

Figure 2. XPS spectra recorded from PdM synthesized catalyst a) Co2p, b) Fe2p, c) Pd3d (for nitrate precursors) and d) Pd3d (for chloride precursors).

Figure 3. TEM images and particle size distribution of the Pd-based electrocatalysts.

Figure 4. Cyclic voltammograms of the Pd-based electrocatalysts recorded in $0.5 \mathrm{M}$ $\mathrm{H}_{2} \mathrm{SO}_{4}$ at $20 \mathrm{mV} \mathrm{s}^{-1}$.

Figure 5. CO stripping voltammograms recorded with the Pd-based electrocatalysts in $0.5 \mathrm{M} \mathrm{H}_{2} \mathrm{SO}_{4}$. At $20 \mathrm{mV} \mathrm{s}^{-1}$ scan rate.

Figure 6. Cyclic voltammograms recoding during FAOR with the $\mathrm{Pd}$-based electrocatalysts in $2.0 \mathrm{M} \mathrm{HCOOH}+0.5 \mathrm{M} \mathrm{H}_{2} \mathrm{SO}_{4}$, at $20 \mathrm{mV} \mathrm{s}^{-1}$ scan rate. In all cases the potential started at $-200 \mathrm{mV}$ in the positive direction.

Figure 7. Potentiostatic current density transients recorded during FAOR, in $2.0 \mathrm{M}$ $\mathrm{HCOOH}$ and $0.5 \mathrm{M} \mathrm{H}_{2} \mathrm{SO}_{4}$, using the synthesized electrocatalysts for two different applied potentials indicated in the figures. The insets show a closed region of the current density at the longest times. 
Fig. 1
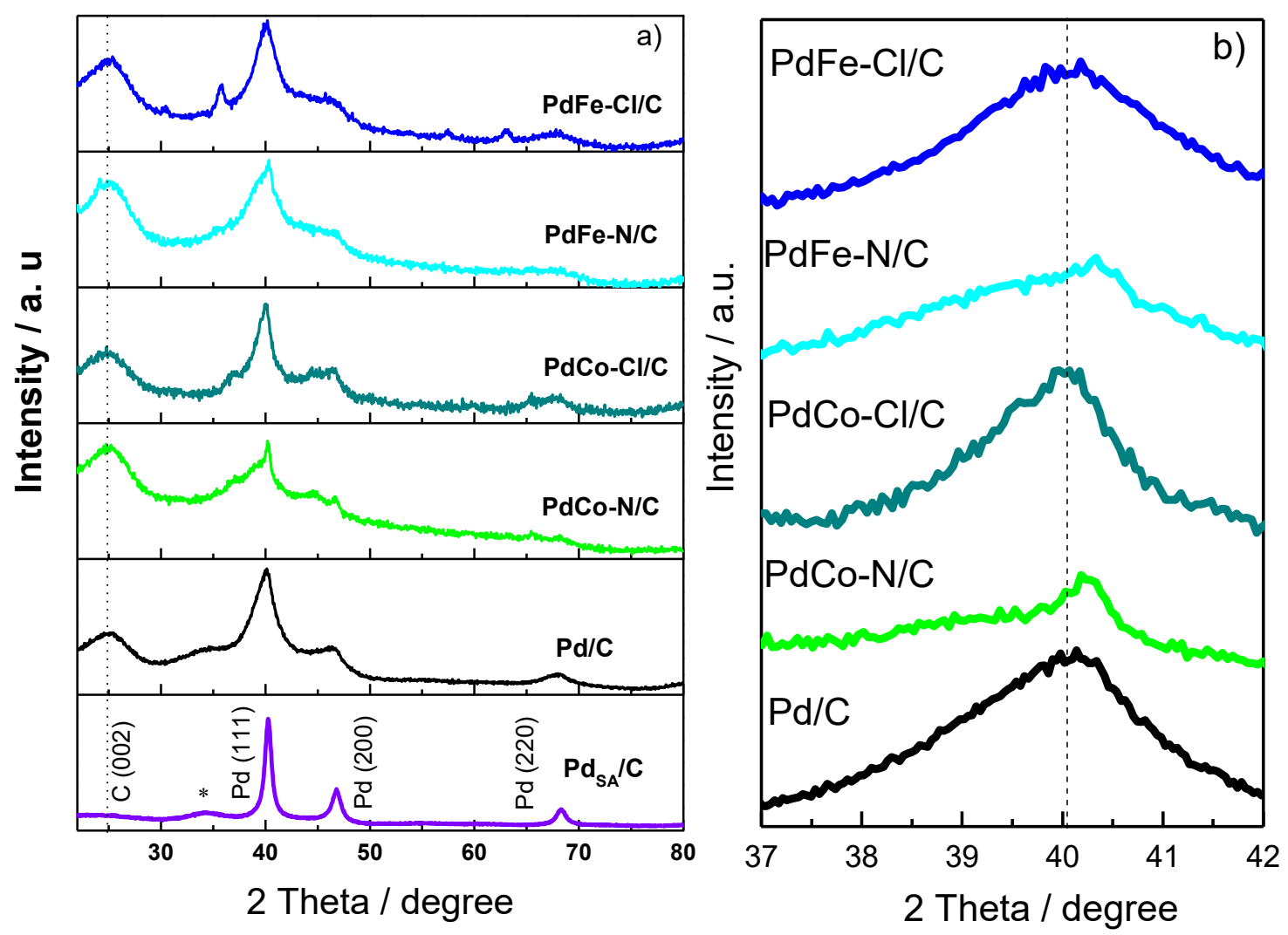

Fig. 2
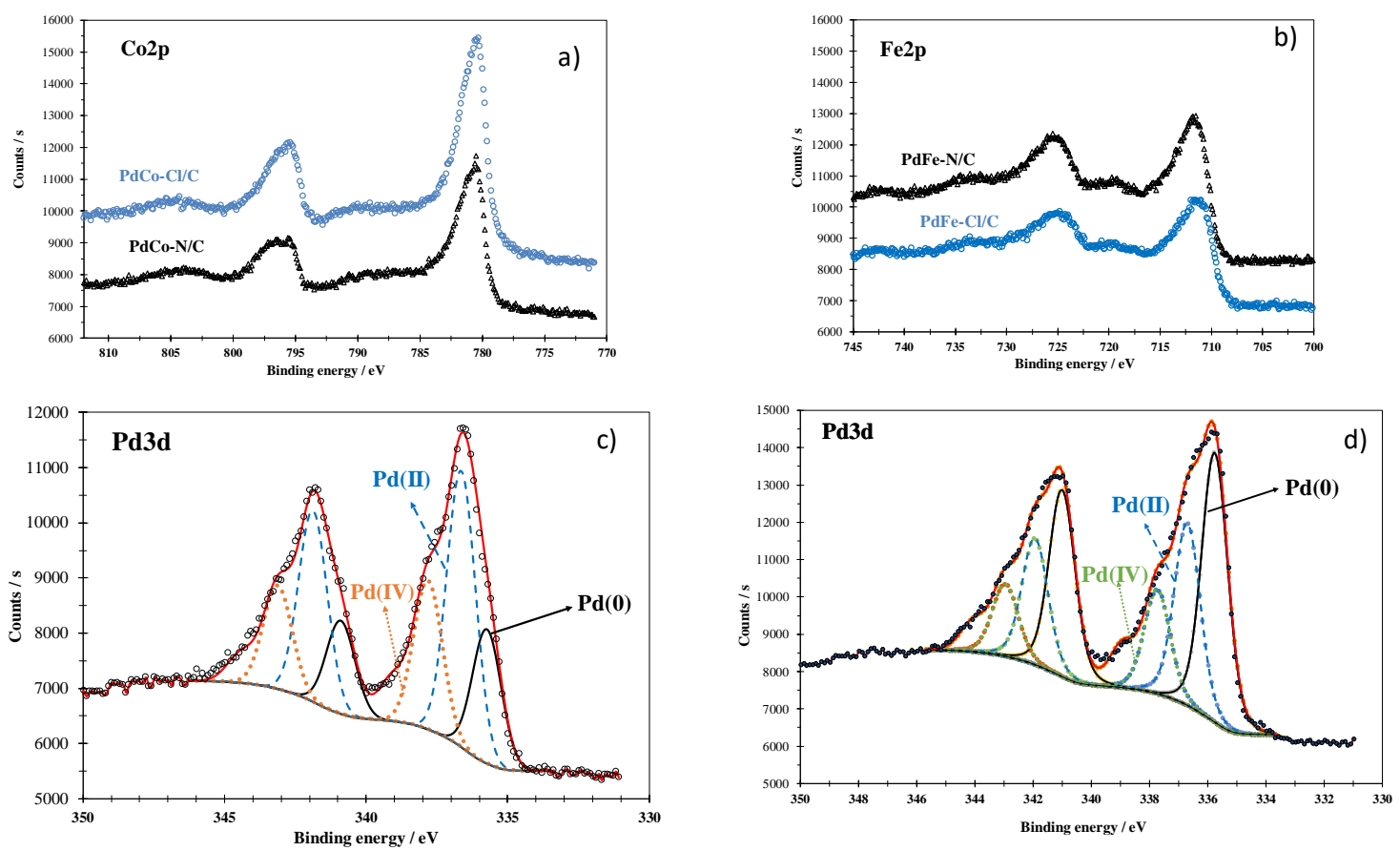
Fig. 3
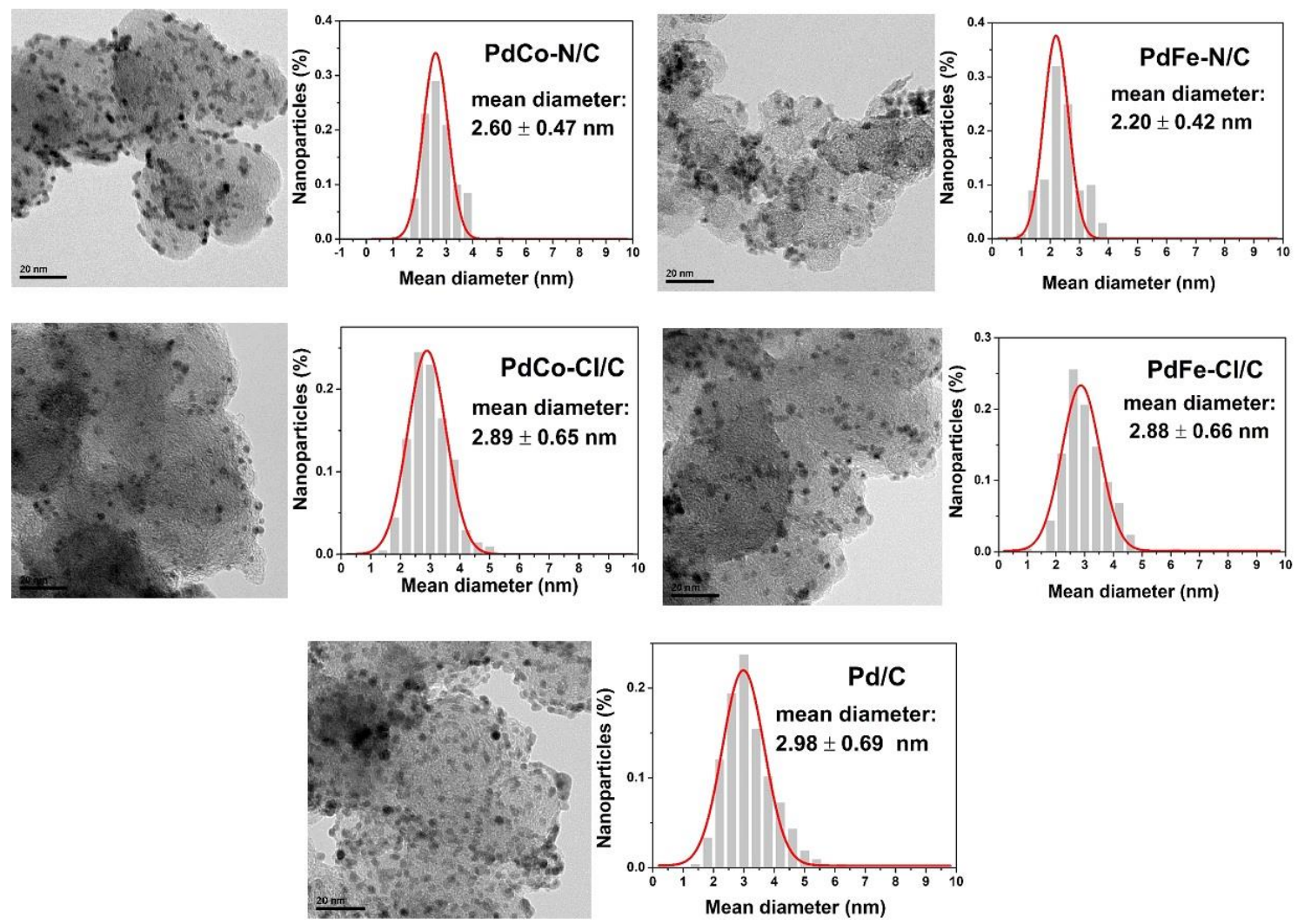

Fig. 4 

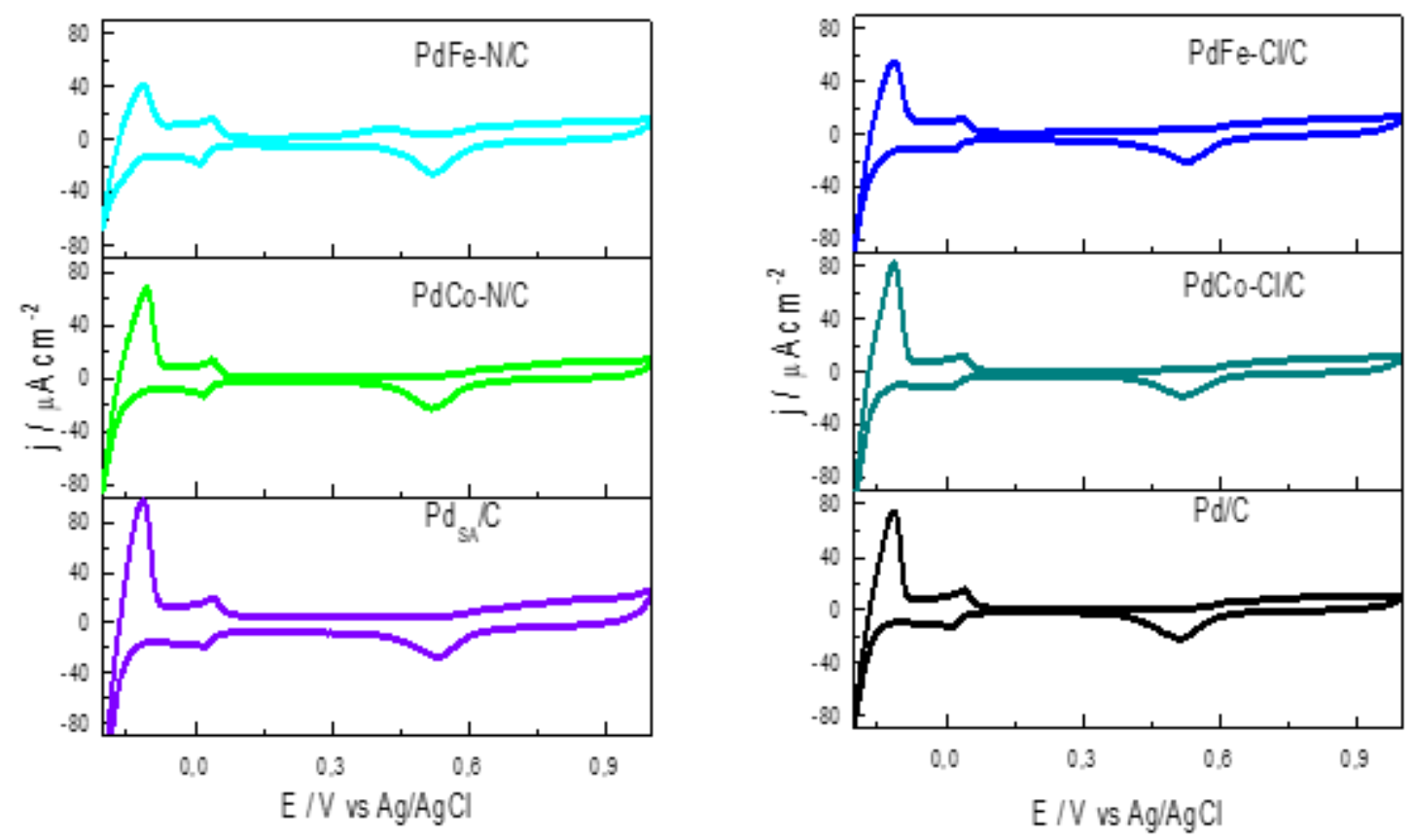

Fig. 5
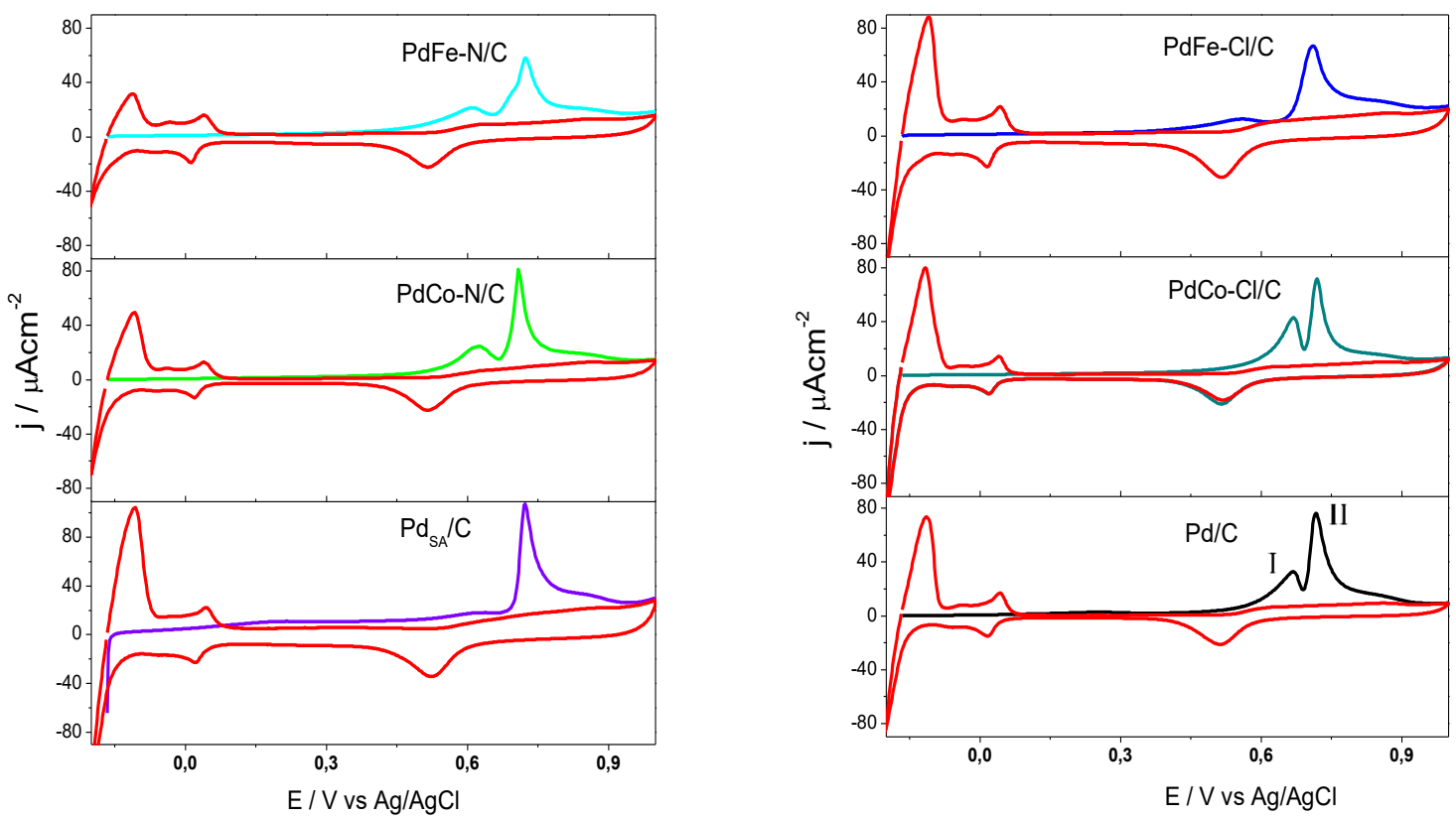
Fig. 6
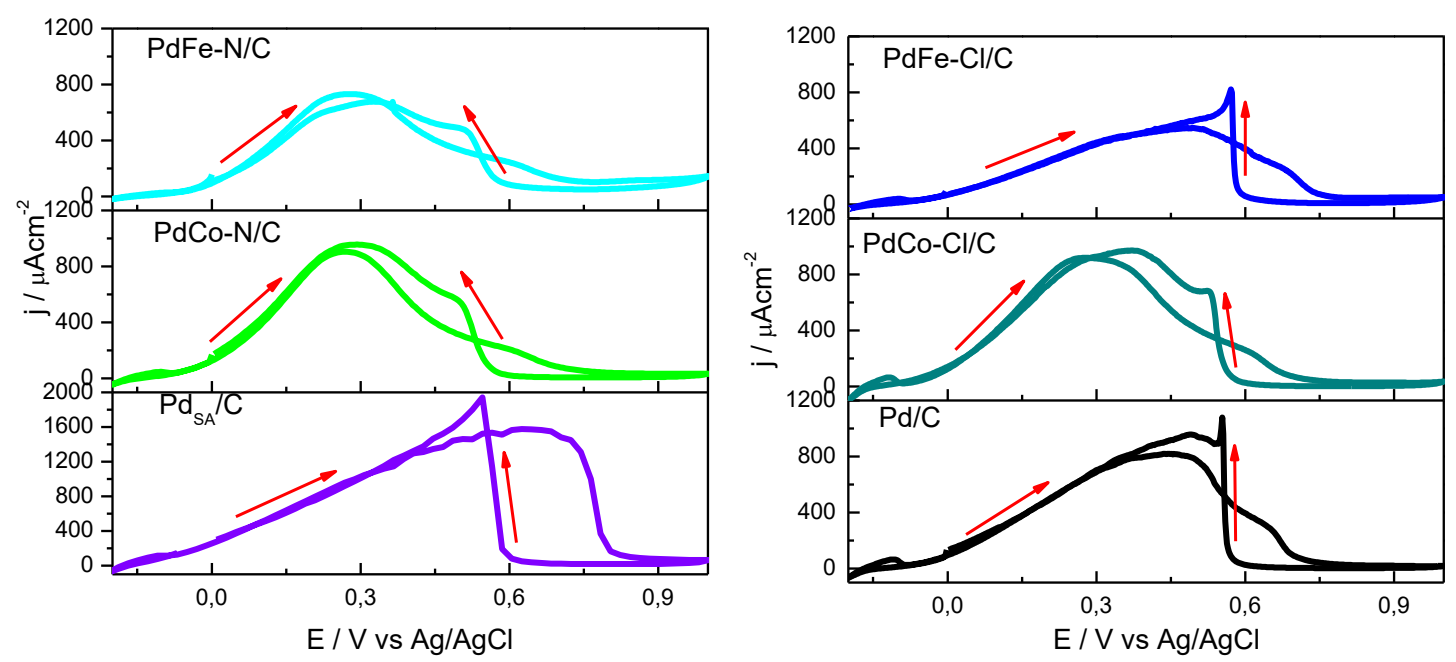

Fig. 7 


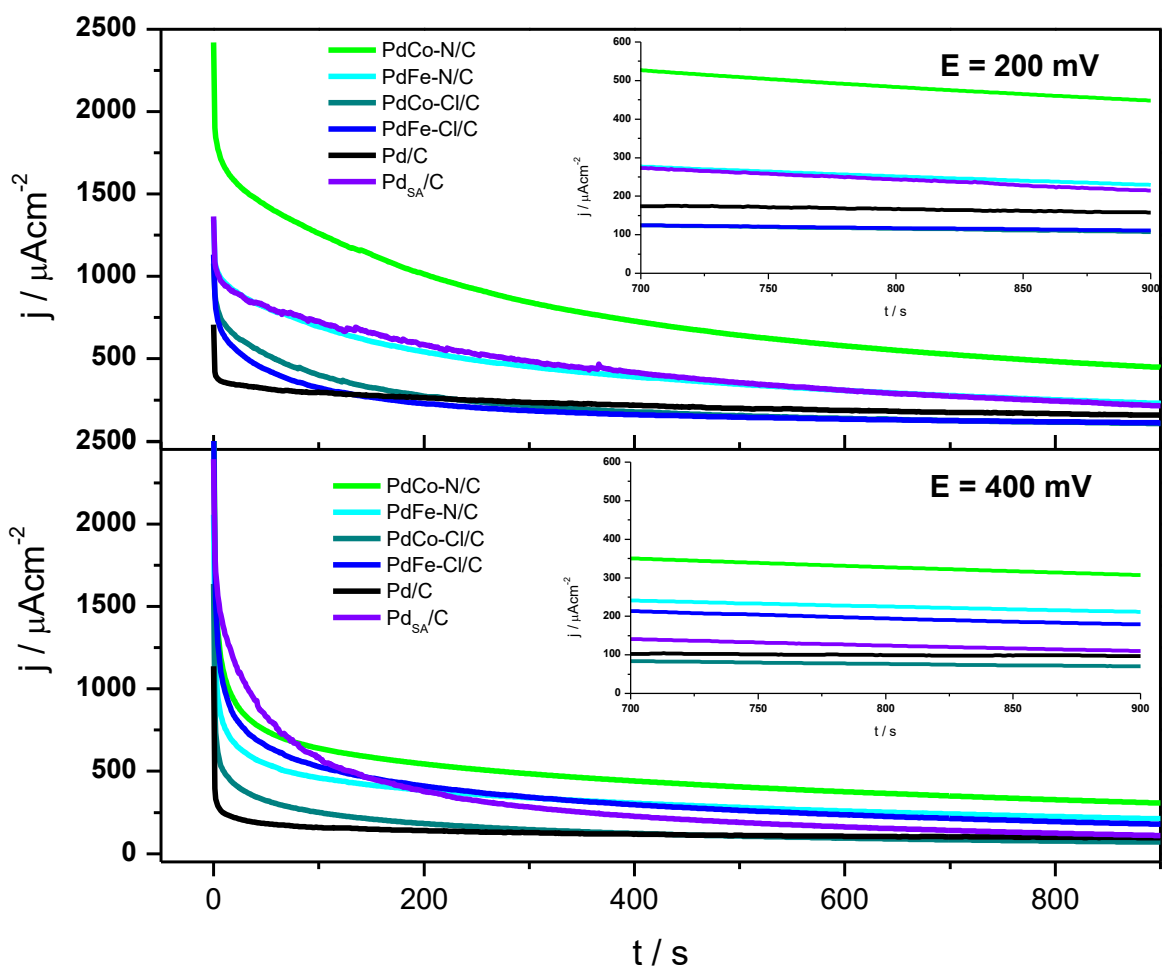

